\title{
Modulation of growth and angiogenic potential of oral squamous carcinoma cells in vitro using salvianolic acid B
}

\author{
Ya Yang ${ }^{1 \dagger}$, Ping $J \mathrm{Ge}^{2 \dagger}$, Long Jiang ${ }^{1}$, Feng $L \mathrm{Li}^{1}$ and Qin Y Zhu ${ }^{1 *}$
}

\begin{abstract}
Background: Our previous studies showed that Salvianolic acid B (Sal B) inhibited 7,12-dimethylbenz[a]anthracene (DMBA)-induced oral carcinogenesis in hamsters and such anti-cancer effects might be related to the inhibition of angiogenesis. This study was aimed to further investigate the anti-proliferative effect of Sal B on the most common type of oral cancer, oral squamous cell carcinoma (OSCC) and the possible mechanisms of action with respect to angiogenesis inhibition.

Methods: Two well-characterized oral squamous cell carcinoma cell lines, CAL27 and SCC4, and premalignant leukoplakia cells were treated with different concentrations of Sal B. Cytotoxicity was assessed by MTT assay. cDNA microarray was utilized to evaluate the expression of 96 genes known to be involved in modulating the biological processes of angiogenesis. Real-time reverse transcription-polymerase chain reaction analysis was conducted to confirm the cDNA microarray data.

Results: Sal B induced growth inhibition in OSCC cell lines but had limited effects on premalignant cells. A total of 17 genes showed a greater than 3-fold change when comparing Sal B treated OSCC cells to the control. Among these genes, HIF-1 $1 \alpha$, TNF $\alpha$ and MMP9 are specifically inhibited, expression of THBS2 was up-regulated.

Conclusions: Sal B has inhibitory effect on OSCC cell growth. The antitumor effect can be attributed to antiangiogenic potential induced by a decreased expression of some key regulator genes of angiogenesis. Sal B may be a promising modality for treating oral squamous cell carcinoma.
\end{abstract}

\section{Background}

Carcinomas of the oral cavity, especially oral squamous cell carcinoma (OSCC), have become an important healthcare problem worldwide. Survival rate of oral carcinoma is lower than most other carcinomas, and has not been improved substantially in past years. The conventional treatment is a combination of surgery, radiation therapy and chemotherapy. Among these strategies, chemotherapy is beneficial for local control and survival improvement. Nevertheless, treatment with current chemotherapeutic drugs does not always substantially

\footnotetext{
*Correspondence: julieyy@163.com

+ Contributed equally

'Department of General Dentistry, Ninth People's Hospital, School of Stomatology, Shanghai Jiao Tong University School of Medicine, Shanghai Key Laboratory of Stomatology, 639 Zhi Zao Ju Road, Shanghai, 200011, China

Full list of author information is available at the end of the article
}

induce a positive response. Therefore, finding an effective therapeutic and preventive strategy for patients of such malignancy is of utmost importance. Screening Chinese medicine herbs or their extracts is believed a promising strategy to find effective chemopreventive agents.

Angiogenesis, the growth of new capillaries from preexisting blood vessels, is essential for cancer to grow beyond minimal size and metastasize [1,2]. Anti-angiogenesis remains a prime therapeutic target and antiangiogenic therapy may be less susceptible to develop treatment resistance. Thus screening natural health products that inhibit angiogenesis is a potential source for investigating new agents to treat oral cancer.

Salvia miltiorrhiza (Danshen), a popular Chinese herb, has been widely and successfully used for treating angina pectoris, myocardial infarction (MI) and stroke [3]. Salvianolic acid B (Sal B), one of the major water- 
soluble compounds of Danshen, is the most abundant and bioactive member of the salvianolic acids in Danshen (exhibiting antioxidant, hepatoprotective and many other actions) [4]. Studies have shown that Sal B possesses many biological activities of the Danshen herb. For example, it was reported to possess anti-inflammatory and anti-oxidative properties, modulation of apoptosis, inhibition of platelet aggregation, improved coronary microcirculation [5-8]. It was also reported that Sal B enhanced angiogenic processes on SVR cells through up-regulation of VEGF and VEGF receptors genes [9], enhanced angiogenesis in vitro and improved skin flap survival in Sprague-Dawley rats [10], and improved the integrity of microvessels after ischemia [11]. But our previous studies showed that Sal B significantly decreased the squamous cell carcinoma (SCC) incidence from $64.7(11 / 17)$ to $16.7 \%(3 / 18)$, with a simultaneous decrease in the immunostaining of HIF-1 $\alpha$ and VEGF protein [12]. These findings suggest that Sal B may serve as a preventive and/or therapeutic agent against oral cancer. And inhibition of angiogenesis may be one of the mechanisms of action. This encouraging in vivo result prompted us to further investigate how Sal B affects oral squamous carcinoma cells growth and prohibits new vessels formation.

\section{Methods}

\section{Drugs and Reagents}

Sal B was a generous gift from Prof. Wei-dong Zhang, Department of Medicinal Chemistry of Nature Product, School of Pharmacy, Second Military Medical University, Shanghai, China. The purity of Sal B was $98 \%$ (determined by high-performance liquid chromatography method with fluorescence). Its molecular weight is 718 , and its molecular formula is $\mathrm{C}_{36} \mathrm{H}_{30} \mathrm{O}_{16}$. Sal B was dissolved in double distilled $\mathrm{H}_{2} \mathrm{O}$ at a concentration of $200 \mathrm{mM}$, filtered through a $0.22 \mu \mathrm{m}$ filter, and stored at $-70^{\circ} \mathrm{C}$. The stock solution was freshly diluted to the desired concentrations with medium immediately before use. Dulbecco's modified Eagle's medium (DMEM) and fetal bovine serum (FBS) were obtained from GIBCO BRL (Grand Island, NY, USA). 3'-(4,5-dimethylthiazol-2yl)-2, 5-diphenyl tetrazolium bromide (MTT) was purchased from BD Pharmingen (USA).

\section{Cell lines}

Three cell lines were used in this study, including CAL27, SCC4 and Leuk1. CAL27 and SCC4 were provided by Laboratory of Oral Tumor and Oral Biology, Shanghai Key Laboratory of Stomatology, Shanghai, China. Leuk1 was a gift from Prof. Li Mao of University of Maryland Dental School, Baltimore, USA. Leuk1 and CAL27 cells were cultured in DMEM (Invitrogen) medium supplemented with $10 \%(\mathrm{v} / \mathrm{v})$ fetal bovine serum, 100 units $/ \mathrm{ml}$ penicillin and 100 units $/ \mathrm{ml}$ streptomycin
(GIBCO). SCC4 cells were maintained in DMEM/F12 supplemented with $10 \% \mathrm{FBS}, 100$ units/ml penicillin and 100 units $/ \mathrm{ml}$ streptomycin. All cells were maintained in a humidified atmosphere of $5 \% \mathrm{CO} 2$ at $37^{\circ} \mathrm{C}$.

\section{Cell viability assay}

The inhibitory effect of Sal B on the cell viability was measured by MTT colorimetric method. Cells were plated into a 96-well plate at a density of $1 \times 10^{3} /$ well in 96-well tissue culture plates. On day two, cells were treated with increasing doses of Sal B (50, 100, $200 \mathrm{ug} /$ $\mathrm{ml}$ ) for $24 \mathrm{~h}, 48 \mathrm{~h}$ and $72 \mathrm{~h}$. After drug treatment, attached cells were incubated with MTT $(0.5 \mathrm{mg} / \mathrm{ml}, 1$ h) for 4 hours and subsequently solubilized in DMSO. The absorbance of each well was measured using an enzyme-linked immunosorbent assay reader at $490 \mathrm{~nm}$. Experiments were performed at least three times.

\section{Nucleic acid isolation and cDNA probe preparation}

Total RNA was isolated from cell culture flasks using RNAbee (Biogenesis), purified using chloroform, precipitated using cold isopropanol, washed using $75 \%$ ethanol. The resulting RNA concentration was measured spectrophotometrically and the quality of RNA was confirmed in agarose gels. cDNA for each sample was obtained by RT-PCR from $500 \mu \mathrm{g}$ RNA in the presence of Biotin-16-dUTP (Roche Cat. No.1-093-070). Briefly, RNAs were denatured at $70^{\circ} \mathrm{C}$ for $10 \mathrm{~min}$ and cDNAs were synthesized at $42^{\circ} \mathrm{C}$ by oligo-dT priming in a final volume of $30 \mu \mathrm{l}$. The labelled cDNAs were purified by spin column chromatography. Then, the biotin-labeled cDNA was fragmented by incubation in fragmentation buffer at $94^{\circ} \mathrm{C}$ for $5 \mathrm{~min}$ and chilled on ice.

\section{cDNA microarray analysis}

GEArray Q Series Angiogenesis Gene Array HS-009 (SuperArray Bioscience), containing 96 genes known to be involved in modulating the biological processes of angiogenesis, was prehybridized at $68^{\circ} \mathrm{C}$ for at least 90 $\mathrm{min}$ before probe addition in hybridization buffer. Then, the fragmented labeled cDNA was applied to the buffer. Hybridization was performed at $60^{\circ} \mathrm{C}$ overnight in a rolling bottle. The arrays were washed twice with $2 \times$ SSC and $0.5 \% \mathrm{SDS}$ at $60^{\circ} \mathrm{C}$ for $30 \mathrm{~min}$; followed by two stringent washes with $0.5 \times$ SSC, $0.5 \%$ SDS at the same temperature and for the same length of time. Finally, damp arrays were sealed in plastic wrap and exposed to imaging plates (BASMP 2040S; Fuji, Nakamura, Japan) for 24 hours, which were then scanned with a HP GeneArray Scanner (Hewlett-Packard, Palo Alto, CA).

\section{Microarray data analysis}

GEArray Analyzer software was used for background subtraction and data normalization. Each GEArrayTM 
Q Series membranes were spotted with negative controls (pUC 18 DNA and blanks) and housekeeping genes, including $\beta$-actin, GAPDH, cyclophinin A and ribosomal protein L13a. All raw signal intensities should be corrected for background by subtracting the minimum value to avoid the appearance of negative numbers. All signal intensities should also be normalized to that of a housekeeping gene. These corrected, normalized signals can then be used to estimate the relative abundance of particular transcripts.

\section{Real-time reverse transcription-polymerase chain reaction (RT-PCR) analysis}

The total RNA prepared for microarray analysis was also used for RT-PCR analysis of selected genes. Total RNA $(2 \mu \mathrm{g})$ from each sample was subjected to reverse transcription using a Superscript first strand cDNA synthesis kit (Invitrogen) according to the manufacturer's protocol. Real-time PCR reactions were then carried out in a $25 \mu \mathrm{L}$ reaction mixture $(1 \mu \mathrm{L}$ of $\mathrm{cDNA}, 12.5 \mu \mathrm{L}$ of $2 \mathrm{X}$ SYBR Green PCR Master Mix, $1 \mu \mathrm{L}$ of $20 \mu \mathrm{M}$ specific gene primer pair, $2.5 \mu \mathrm{L}$ of PCR buffer, $3 \mu \mathrm{L}$ of $\mathrm{MgCL}_{2}$ solution, $3 \mu \mathrm{L}$ of dNTP solution, 3 units of Taq and 23 $\mu \mathrm{L}$ of $\left.\mathrm{H}_{2} \mathrm{O}\right)$ in an Rotor-Gene 3000 Realtime PCR machine (Corbett Research). The PCR program was initiated by $2 \mathrm{~min}$ at $50^{\circ} \mathrm{C}$ and $10 \mathrm{~min}$ at $95^{\circ} \mathrm{C}$ before 40 thermal cycles, each of $20 \mathrm{~s}$ at $94^{\circ} \mathrm{C}$ and $30 \mathrm{~s}$ at $72^{\circ} \mathrm{C}$. Data were analyzed according to the comparative cycle threshold $(\mathrm{Ct})$ method and were normalized by $\beta$-actin expression in each sample. Melting curves for each PCR reaction were generated to ensure the purity of the amplification product.

\section{Statistical analysis}

The significance of results obtained from the control and treated groups was analyzed using the paired Student's t-test. Means and standard deviations were calculated. $P<0.05$ was regarded as statistically significant.

\section{Results}

\section{Effects of Sal B on cell viability}

We evaluated the effects of Sal B on cell growth in the human oral squamous cell carcinoma cell lines CAL27, SCC4 and immortalized oral leukoplakia cell line Leuk1. Cells were incubated with increasing doses of Sal B (50, $100,200 \mu \mathrm{M})$ or vehicle control for $24,48 \mathrm{~h}$ and $72 \mathrm{~h}$ respectively; and cell viability was determined by a conventional tetrazolium-based (MTT) assay. As shown in Figure $1 \mathrm{~A}$ and $1 \mathrm{~B}$, Time-dependent growth inhibition was seen in CAL27 cells. The SCC4 cells seemed to be stimulated after 24 hour, but moderate inhibited at higher concentration after $48 \mathrm{~h}$ and inhibited after $72 \mathrm{~h}$. The $\mathrm{IC}_{50}$ values were $51 \mu \mathrm{g} / \mathrm{ml}$ and $87 \mu \mathrm{g} / \mathrm{ml}$, respectively. In contrast, Sal B had a limited effect on the growth of Leuk1 (Figure 1C).

\section{Expression Profiling of Sal B treated cells}

We analyzed the gene expression profiles of Sal B treated CAL27 and SCC4. In comparison of Sal B treated cells with the control, we identified only two genes of which the scaled average difference values varied by $\geq 3$ fold in both of the OSCC cell lines. One is down-regulated hypoxia inducing factor ${ }_{1 \alpha}$ (HIF-1 $\left.\alpha\right)$, the other one is up-regulated Thrombospondin-2 (THBS2). Then we relaxed the stringency of our selection criteria to identify genes that exhibited a 3 -fold expression difference in Sal B treated CAL27 or SCC4 cells relative to the control cells. The results demonstrated that 17 genes showing a greater than 3-fold change after Sal B treatment. Among these, 15 genes were down-regulated and 2 were up-regulated (Table 1, Table 2 and Figure 2). Genome profiles are available online through the NCBI Gene Expression Omnibus http://www.ncbi.nlm.nih.gov/ geo/query/acc.cgi?acc=GSE29416SE29416.

\section{Target verification by RT-PCR}

To verify the alterations of gene expression at the mRNA level, which appeared on the microarray, we chose four genes $\left(\mathrm{HIF}_{1 \alpha}, \mathrm{TNF}_{\alpha}, \mathrm{MMP}_{9}, \mathrm{THBS} 2\right)$ with varying expression profiles for real-time RT-PCR analysis. The results of real-time RT-PCR analysis for these selected genes were consistent with the microarray data. Gene expression alterations were similar by real-time RT-PCR analysis, although the fold changes in the expression level differed somewhat in the two analytical methods (Figure 3).

\section{Discussion}

Clinical practice for years has proven that Salvia miltiorrhiza has anti-cancer potential and its application in the treatment of a variety of cancers has achieved surprising effects $[13,14]$. However, most of the studies about Sal $\mathrm{B}$, one of the major biologically active components of Salvia miltiorrhiza, were focused on its effects on cardiovascular disorders. There are few data available about the effect of this component on cancer. It was for this reason that Sal B was evaluated in our study for its chemopreventive and chemotherapeutic potential against OSCC.

In the present study we investigated whether Sal B has any inhibitory properties on OSCC cells and potentially malignant Leuk 1 cells, in order to provide more documentation on the possible application of Sal B on OSCCs and oral premalignant lesions. We have shown that Sal B potently inhibited cell growth and induced apoptosis in OSCC cell lines CAL27 and SCC4. However, Sal B was much less active in Leuk1. The 


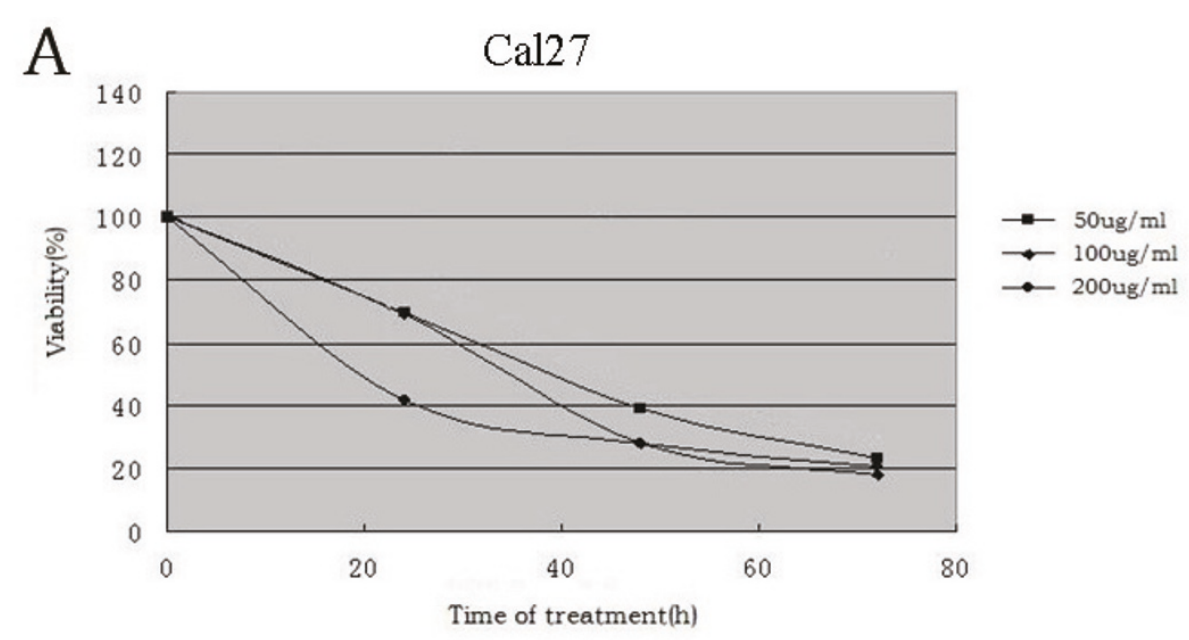

B

SCC4
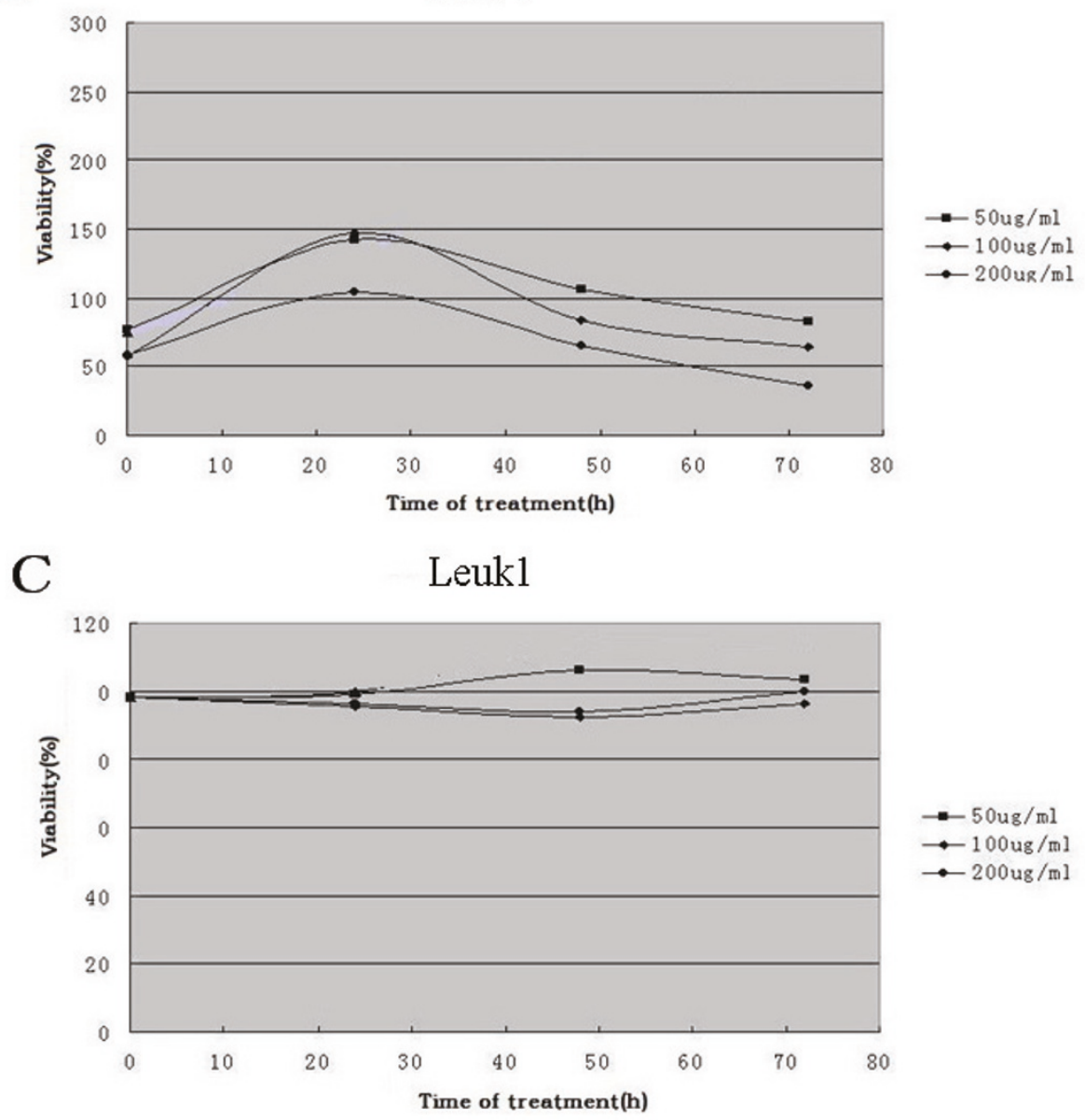

Figure 1 Effects of Sal B on growth of human oral squamous cell carcinoma cells CAL27, SCC4 and oral precancerous cells Leuk1. Cells $\left(1 \times 10^{4}\right)$ were treated with increasing concentrations of Sal B $(50,100,200 \mu \mathrm{g} / \mathrm{mL})$ for $72 \mathrm{~h}$. Viable cells were measured by MTT assay and expressed as a percentage of control. All values are means of three independent experiments \pm SD (bars). Time-dependent growth inhibition was seen in CAL27 cells. The SCC4 cells seemed to be stimulated after $24 \mathrm{~h}$, but moderate inhibited at higher concentration after $48 \mathrm{~h}$ and inhibited after $72 \mathrm{~h}$. No growth inhibition was also seen in Leuk1 cells. The significance of results obtained from the control and treated groups was analyzed using the paired Student's t-test. Means and standard deviations were calculated. $P<0.05$ was regarded as statistically significant. 
Table 1 Angiogenesis-related Genes Significantly Affected by Sal B in CAL27 cells

\begin{tabular}{llll}
\hline & gene & code & Mean fold difference \\
\hline Down-regulated & Tenascin $C$ & NM_011607 & 10.41 \\
& Osteopontin & NM_009263 & 8.50 \\
& HIF-1 $\alpha$ & NM_010431 & 8.19 \\
& TGFb 1 & NM_011577 & 7.93 \\
& Cox-2 & NM_011198 & 7.61 \\
& HGF & XM_131908 & 5.99 \\
& Scya 2 & NM_011333 & 5.15 \\
& IL-10 & NM_010548 & 4.50 \\
& TGFbR 2 & NM_009371 & 3.55 \\
& Mmp 2 & NM_011697 & 3.48 \\
\hline Up-regulated & THBS2 & NM_011581 & 3.42
\end{tabular}

mechanisms accounting for this selective growth inhibition need to be further investigated. It needs to be noted that Sal B undergoes degradation in normal saline solution which will affect its anti-cancer effect. But we found in this study that Sal B still significantly inhibited the growth of CAL27 and SCC4 cells after treatment over 24 hours. We suppose its anti-cancer effect will be more potent if Sal B could be used in a solid state.

Results of another study from this laboratory showed that the growth inhibitory effect of Sal B was related to the apoptosis-inducing effect of Sal B (determined by flow cytometry analysis, data not shown). The detailed mechanism(s) of the pro-apoptotic effect of Sal B on OSCC cells remains unclear, as we have not attempted to investigate this aspect of action in this study. But this finding, together with our previous in vivo results, suggests that Sal B may be a good candidate for therapy in patients with these malignancies.

Further microarray-based expression profiling and quantitative RT-PCR analyses were performed to confirm whether anti-angiogenesis is one of the possible mechanisms of Sal B-induced growth inhibition in

Table 2 Angiogenesis-related Genes Significantly Affected by Sal B in SCC4 cells

\begin{tabular}{|c|c|c|c|}
\hline & gene & code & Mean fold difference \\
\hline \multirow[t]{9}{*}{ Down-regulated } & $\mathrm{HIF}-1_{\alpha}$ & NM_010431 & 5.75 \\
\hline & $\mathrm{Mmp}_{9}$ & & 4.17 \\
\hline & TGF $b_{3}$ & NM_013599 & 4.01 \\
\hline & VEGF & & 3.42 \\
\hline & VEGF-C & NM_009368 & 3.21 \\
\hline & TNFa & & 3.05 \\
\hline & & NM_009505 & \\
\hline & & NM_009506 & \\
\hline & & NM_013693 & \\
\hline \multirow[t]{2}{*}{ Up-regulated } & THBS2 & NM_011581 & 3.23 \\
\hline & Timp1 & NM_011593 & 3.15 \\
\hline
\end{tabular}

CAL27 and SCC4 cells, the two OSCC cell lines sensitive to the growth inhibitory effects of Sal B. The results showed that HIF- $1 \alpha$ is down-regulated by $\geq 3$ fold in both of the Sal B treated CAL27 cells and SCC4 cells. This result was consistent with our previous immunostaining studies. In our previous study, we observed that the formation of microvessels, as well as the expression of pro-angiogenic factors HIF-1 $\alpha$ and VEGF, was inhibited in dysplasia and SCC by Sal B [12]. HIF- $1 \alpha$ is a transcription factor activated in response to cellular hypoxia. Being stabilized under decreased tissue oxygen concentration, it works as a cellular oxygen-sensing system, and trans-activates a large number of genes. Included among these are erythropoietin, glucose transporters, glycolytic pathway enzymes, and inducible nitric oxide synthase [15-17]. Discoveries have shown that hypoxia activates HIF-1 $\alpha$, which functions as master switches to induce expression of several angiogenic factors including VEGF, nitric oxide synthase (NOS), platelet-derived growth factor (PDGF) and Ang2. Alteration and over-expression of HIF- $1 \alpha$ has been detected in a variety of solid tumors, including breast, lung, ovarian and oral cancer $[18,19]$. These observations, together with our results, strongly implied that inhibition of HIF- $1 \alpha$ activation by Sal B, which resulted in lowered expression of downstream pro-angiogenic genes, may be a key mechanism of cell growth inhibition and anti-angiogenesis on oral cancers. Their relative protein expression levels and whether such an action can be demonstrated in vivo remains to be confirmed.

However, the anti-angiogenic effect of Sal B seemed contradictive to some previous studies which showed that Sal B might improve microcirculation by augmenting VEGF expression and promoting angiogenesis. [9-11,20]. Thrombospondins (TSPs) are known to inhibit neovascularization by induction of endothelial cell apoptosis through interaction with CD36 [21], inhibition of metalloproteinase activity [22], and inhibition of cellcycle progression [23]. In addition to these well-known effects on endothelial cell proliferation and apoptosis, maintenance of vascular integrity is another notable function of TSPs [24-26]. In this study, thrombospondin-2 (THBS2) expression was up-regulated by $\geq 3$-fold in both of the Sal B treated CAL27 cells and SCC4 cells. Another study in our lab showed that in the Sal B treated samples, the mural cell coverage index was significantly higher than that of the control. And the organization of mural cells in the two groups of samples was dramatically different (data not shown). This suggests that Sal B may prevent the formation of new vessels by promoting vascular maturation. It is possible that the pro-angiogenic effect of Sal B induces formation of mature vessels with efficient irrigation function. The 


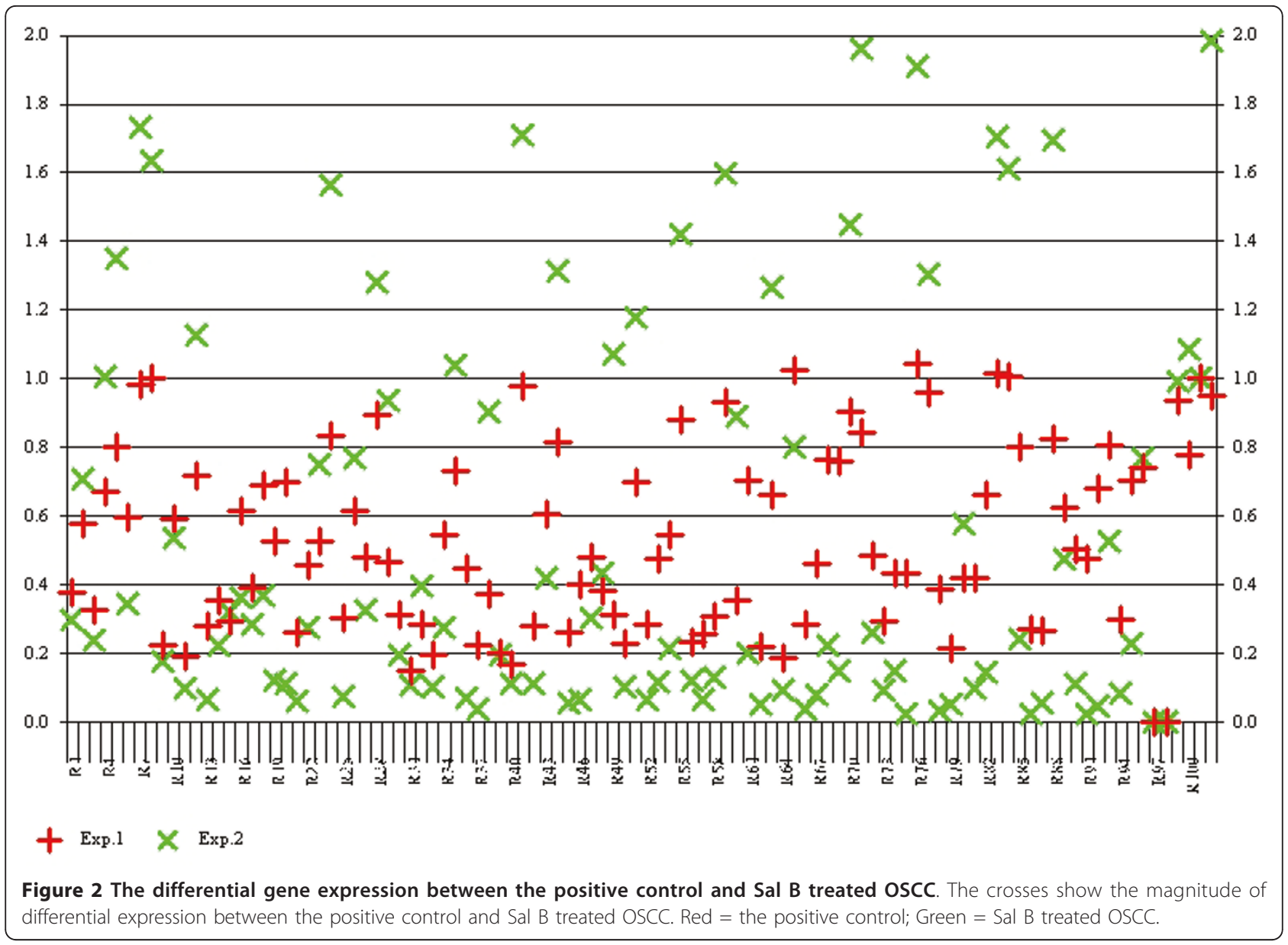

new vessels are different from the angiogenesis in tumors which leads to the formation of a poorly organized vasculature characterized by tortuous and leaky vessels unable to support efficient blood flow (Further investigation will carried out to clarify this point). The potent effect of Sal B on blood circulation may reduce the hypoxia stress in the local tissues, thus inhibit the uncontrolled formation of leaky vasculature. Based upon this information, the current results may be in line with those of previous studies.

Several angiogenesis-associated genes, including Tenascin-C, Osteopontin, TGF- ${ }_{\beta}$, Cox-2, HGF, MMP- ${ }_{-2}$ and MMP-9 also displayed variable expression in this study. Expression of these genes was changed $\geq 3$-fold in CAL27 cells or SCC4 cells. This result was consistent with earlier studies which reported that Sal B attenuates LPS-induced Cox-2, MMP-2 and MMP-9 expression in human aortic smooth muscle cells. $[27,28]$ We found that these genes also play important roles in other ways that can affect cell signaling, the apoptotic pathway, cell metastasis, and other cellular behaviors. For example, expression of COX-2 was inhibited in Sal B treated
OSCC cells. Over-expression of COX-2 is thought to contribute to carcinogenesis by stimulating cell proliferation [29], inhibiting apoptosis [30], and enhancing angiogenesis [31]. Such genes as Tenascin-C, Osteopontin and MMP, which were reported to contribute to tumor metastasis [32-35], were inhibited by Sal B in this study. Therefore, this suggested that Sal B may exert multiple effects on oral carcinogenesis. Further research is required to investigate whether other mechanisms, as anti-metastasis, anti-oxidant and anticoagulation effect, will contribute towards the chemopreventive effect of Sal B on OSCC cells.

\section{Conclusion}

Our study suggests that Sal B has cytotoxic effect on OSCC cells. Its antitumor effect could be attributed to its anti-angiogeneic effect. Sal B may function by inhibiting expressions of such angiogenesis-associated genes as HIF-1 $\alpha$, THBS2, Tenascin-C, Osteopontin, TGFb1, Cox2, HGF, and $\mathrm{MMP}_{2}$. Translational investigations to determine whether these angiogenesis-associated genes are regulated by Sal B in OSCC tumors in vivo and 


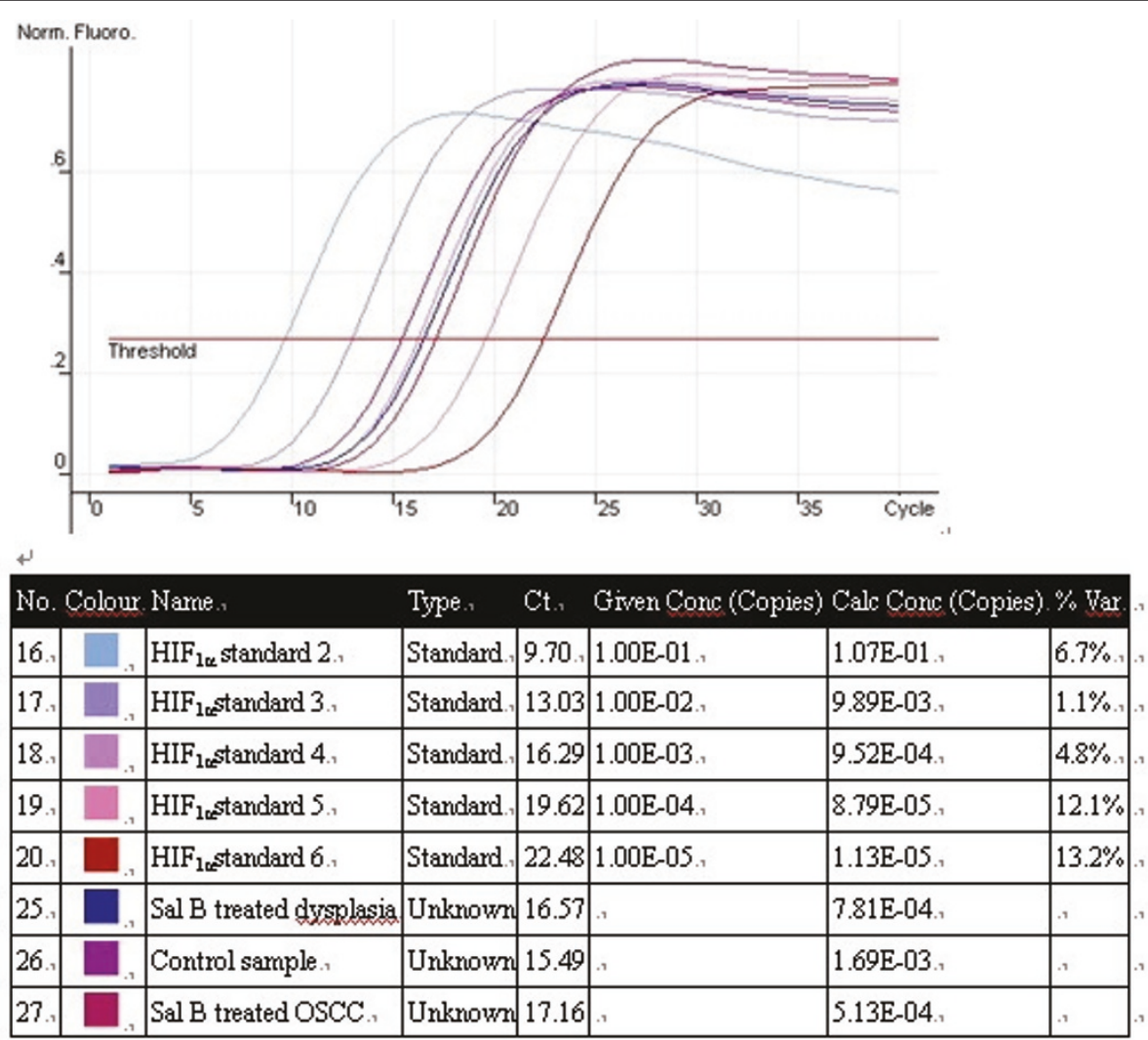

Figure 3 Amplification plots of HIF-1 $1_{\alpha}$ by quantitative real-time PCR.

whether such regulations correlate with clinical response should further elucidate the mechanisms of action of this new agent in OSCC.

\section{Abbreviations}

DMBA: 7,12-dimethylbenz[a]anthracene; OSCC: oral squamous cell carcinoma; Sal B: Salvianolic acid B; MVD: microvessel density; HIF-1a: Hypoxia inducible factor 1, alpha subunit; TNFa: tumor necrosis factor-a; VEGF: vascular endothelium growth factor; MMP9: Matrix metalloproteinase 9; COX-2: Cyclooxygenase 2; TSPs: Thrombospondins; THBS2: Thrombospondin 2

\section{Acknowledgements}

This work was supported by research Grants 81000439 from National Natural Science Foundation of China; by research Grant jdy09050 from Shanghai Excellent Young Teacher Research Foundation; by Shanghai Leading Academic Discipline Project S30206; also by Science and Technology Commission of Shanghai Municipality Grant 08DZ2271100 and 08JC1414500, the Scientific Research Foundation for the Returned Overseas Chinese Scholars, State Education Ministry Grant 2008-0890-09, and Innovation Program of Shanghai Municipal Education Commission Grant $09 Z Z 116$.

\section{Author details}

'Department of General Dentistry, Ninth People's Hospital, School of Stomatology, Shanghai Jiao Tong University School of Medicine, Shanghai Key Laboratory of Stomatology, 639 Zhi Zao Ju Road, Shanghai, 200011, China. ${ }^{2}$ Department of Endodontics, Tongji Hospital of Stomatology, Tongji University, 399 Middle Yanchang Road, Shanghai, 200072, China.

\section{Authors' contributions}

YY and QZ were responsible for the study design, interpretation of the data and revision of the manuscript. YY and PG carried out the experimental work, $\mathrm{L}$ and $\mathrm{FL}$ did the statistical analysis. YY and PG prepared the manuscript, QZ made critical revisions. All authors read and approved of the final manuscript.

\section{Competing interests}

The authors declare that they have no competing interests.

Received: 23 February 2011 Accepted: 5 July 2011

Published: 5 July 2011

\section{References}

1. Fox SB: Tumor angiogenesis and prognosis. Histopathology 1997, 30(3):294-301.

2. Folkman J: The oral of angiogenesis in tumor growth. Semin Cancer Biol 1992, 3(2):65-71

3. Henry TD, Annex BH, McKendall GR, Azrin MA, Lopez JJ, Giordano FJ, Shah PK, Willerson JT, Benza RL, Berman DS, Gibson CM, Bajamonde A, Rundle AC, Fine J, McCluskey ER, VIVA Investigators: The VIVA trial: vascular endothelial growth factor in ischemia for vascular angiogenesis. Circulation 2003, 107(10):1359-1365.

4. Kastrup J, Jørgensen E, Rück A, Tägil K, Glogar D, Ruzyllo W, Bøtker HE, Dudek D, Drvota V, Hesse B, Thuesen L, Blomberg P, Gyöngyösi M, Sylvén C, Euroinject One Group: Direct intramyocardial plasmid vascular endothelial growth factor- $\mathrm{A}_{\text {_ }}$ gene therapy in patients with stable severe angina pectoris A randomized double-blind placebo-controlled study: the Euroinject One trial. J Am Coll Cardiol 2005, 45(7):982-988.

5. Hao Y, Xie T, Korotcov A, Zhou Y, Pang X, Shan L, Ji H, Sridhar R, Wang P, Califano J, Gu X: Salvianolic acid B inhibits growth of head and neck squamous cell carcinoma in vitro and in vivo via cyclooxygenase- 2 and apoptotic pathways. International Journal of Cancer 2009, 124(9):2200-2209.

6. Zhao Y, Hao Y, Ji H, Fang Y, Guo Y, Sha W, Zhou Y, Pang X, Southerland WM, Califano JA, Gu X: Combination effects of salvianolic acid $B$ with low-dose celecoxib on inhibition of head and neck 
squamous cell carcinoma growth in vitro and in vivo. Cancer Prevention Research 2010, 3(6):787-796.

7. Wang SX, Hu LM, Gao XM, Guo H, Fan GW: Anti-inflammatory activity of salvianolic acid B in microglia contributes to its neuroprotective effect. Neurochemical Research 2010, 35(7):1029-1037.

8. Tsai MK, Lin YL, Huang YIT: Effects of salvianolic acids on oxidative stress and hepatic fibrosis in rats. Toxicology and Applied Pharmacology 2010, 242(2):155-164.

9. Lay IS, Chiu JH, Shiao MS, Lui WY, Lui WY: Crude extract of Salvia miltiorrhiza and salvianolic acid $B$ enhance in vitro angiogenesis in murine SVR endothelial cell line. Planta Med 2003, 69(1):26-32

10. Lay IS, Hseih CC, Chiu JH, Shiao MS, Liu WY, Wu CW: Salvianolic acid b enhances in vitro angiogenesis and improves skin flap survival in sprague-dawley rats. J Surg Res 2003, 115(2):279-285.

11. Tang M, Feng WH, Zhang Y, Zhong J, Zhang JT: Salvianolic acid B mproves motor function after cerebral ischemia in rats. Behavioural Pharm 2006, 17(5-6):493-498.

12. Zhou ZT, Yang Y, Ge JP: The preventive effect of salvianolic acid $B$ on the malignant transformation of DMBA-induced oral premalignant lesions in hamster. Carcinogenesis 2006, 27(4):826-832.

13. Chen XG, Li Y, Yan CH, Li LN, Han R: Cancer chemopreventive activities of S-3-1, a synthetic derivative of danshinone. J Asian Nat Prod Res 2001, 3(1):63-75.

14. Liu J, Yang CF, Wasser S, Shen HM, Tan CE, Ong CN: Protection of salvia miltiorrhiza against aflatoxin-B1-induced hepatocarcinogenesis in Fischer 344 rats dual mechanisms involved. Life Sci 2001, 69(3):309-326.

15. Bunn HF, Poyton RO: Oxygen sensing and molecular adaptation to hypoxia. Physiol Rev 1996, 76(3):839-885.

16. Semenza GL: Regulation of mammalian $\mathrm{O}_{2}$ homeostasis by hypoxiainducible factor 1. Annu Rev Cell Dev Biol 1999, 15:551-578.

17. Wenger RH, Gassmann M: Oxygen(es) and the hypoxia-inducible factor-1. Biol Chem 1997, 378(7):609-616.

18. Zhong H, De Marzo AM, Laughner E, Lim M, Hilton DA, Zagzag D, Buechler P, Isaacs WB, Semenza GL, Simons JW: Overexpression of hypoxia-inducible factor $1 a$ in common human cancers and their metastases. Cancer Res 1999, 59(22):5830-5835.

19. Talks KL, Turley H, Gatter KC, Maxwell PH, Pugh CW, Ratcliffe PJ, Harris AL: The expression and distribution of the hypoxia-inducible factors HIF-1a and HIF-2a in normal human tissues, cancers, and tumor-associated macrophages. Am J Pathol 2000, 157(2):411-421.

20. He HB, Yang XZ, Shi MQ, Zeng XW, Wu LM, Li LD: Comparison of cardioprotective effects of salvianolic acid $B$ and benazepril on large myocardial infarction in rats. Pharmacological reports 2008, 60(3):369-381.

21. Simantov R, Silverstein RL: CD36: a critical anti-angiogenic receptor. Front Biosci 2003, 8:s874-s882.

22. Rodriguez-Manzaneque JC, Lane TF, Ortega MA, Hynes RO, Lawler J, IruelaArispe ML: Thrombospondin-1 suppresses spontaneous tumor growth and inhibits activation of matrix metalloproteinase- 9 and mobilization of vascular endothelial growth factor. Proc Natl Acad Sci USA 2001, 98:12485-12490.

23. Armstrong LC, Björkblom B, Hankenson KD, Siadak AW, Stiles CE, Bornstein P: Thrombospondin 2 inhibits microvascular endothelial cell proliferation by a caspase-independent mechanism. Mol Biol Cell 2002, 13:1893-1905.

24. Lange-Asschenfeldt B, Weninger W, Velasco P, Kyriakides TR, von Andrian $U H$, Bornstein P: Increased and prolonged inflammation and angiogenesis in delayed-type hypersensitivity reactions elicited in the skin of thrombospondin-2-deficient mice. Blood 2002, 99:538-545.

25. Nunes SS, Greer KA, Stiening CM, Chen HYS, Kidd KR, Schwartz MA, et al: Implanted Microvessels Progress through Distinct Neovascularization Phenotypes. Microvasc Res 2010, 79(1):10.

26. Chen J, Somanath PR, Razorenova O, Chen WS, Hay N, Bornstein P, Byzova TV: Akt1 regulates pathological angiogenesis, vascular maturation and permeability. vivo Nat Med 2005, 11(11):1188-1196.

27. Lin SJ, Lee IT, Chen YH, Lin FY, Sheu LM, Ku HH, Shiao MS, Chen JW, Chen YL: Salvianolic acid B attenuates MMP-2 and MMP-9 expression in vivo in apolipoprotein-E-deficient mouse aorta and in vitro in LPStreated human aortic smooth muscle cells. J Cell Biochem 2007, 100:372-384

28. Chen YL, Hu CS, Lin FY, Chen YH, Sheu LM, Ku HH, Shiao MS, Chen JW, Lin SJ: Salvianolic acid B attenuates cyclooxygenase-2 expression in vitro in LPStreated human aortic smooth muscle cells and in vivo in the apolipoprotein-Edeficient mouse aorta. J Cell Biochem 2006, 98:618-631.

29. Tsujii M, DuBois RN: Alterations in cellular adhesion and apoptosis in epithelial cells overexpressing prostaglandin endoperoxide synthase 2 . Cell 1995, 83(3):705-716.

30. Marnett $\sqcup$ : Generation of mutagens during arachidonic acid metabolism. Cancer Metastasis Rev 1994, 13(3-4):303-308.

31. Leahy KM, Koki AT, Masferrer JL: Role of cyclooxygenases in angiogenesis. Curr Med Chem 2000, 7(11):1163-1170.

32. Ide M, Saito K, Tsutsumi S, Tsuboi K, Yamaguchi S, Asao T, Kuwano H, Nakajima T: Over-expression of 14-3-3sigma in budding colorectal cancer cells modulates cell migration in the presence of tenascin-C. Oncol Rep Dec 2007, 18(6):1451-1456.

33. Zheng H, Tsuneyama K, Cheng C, Cui Z, Nomoto K, Takano Y: Expression of KAl1 and tenascin, and microvessel density are closely correlated with liver metastasis of gastrointestinal adenocarcinoma. J Clin Pathol 2007, 60(1):50-56.

34. Suzuki M, Mose E, Galloy C, Tarin D: Osteopontin gene expression determines spontaneous metastatic performance of orthotopic human breast cancer xenografts. Am J Pathol 2007, 171(2):682-692.

35. Mendes O, Kim HT, Stoica D: Expression of MMP2, MMP9 and MMP3 in breast cancer brain metastasis in a rat model. Clin Exp Metastasis 2005, 22(3):237-246.

\section{Pre-publication history}

The pre-publication history for this paper can be accessed here: http://www.biomedcentral.com/1472-6882/11/54/prepub

doi:10.1186/1472-6882-11-54

Cite this article as: Yang et al:: Modulation of growth and angiogenic potential of oral squamous carcinoma cells in vitro using salvianolic acid B. BMC Complementary and Alternative Medicine 2011 11:54.

\section{Submit your next manuscript to BioMed Central and take full advantage of:}

- Convenient online submission

- Thorough peer review

- No space constraints or color figure charges

- Immediate publication on acceptance

- Inclusion in PubMed, CAS, Scopus and Google Scholar

- Research which is freely available for redistribution

Submit your manuscript at www.biomedcentral.com/submit
C Biomed Central 